Brit. F. vener. Dis. (1974) 50, 341

\title{
Treponema pallidum haemagglutination test as a screening procedure for the diagnosis of syphilis
}

\author{
H. YOUNG AND C. HENRICHSEN \\ Bacteriology Department, University of Edinburgh \\ AND \\ D. H. H. ROBERTSON \\ Department of Sexually-Transmitted Diseases, The Royal Infirmary of Edinburgh
}

The serological diagnosis of syphilis relies upon the widespread use of non-specific screening tests, such as the cardiolipin Wassermann reaction (CWR) and the Venereal Diseases Research Laboratory (VDRL) slide test, in combination with the Reiter protein complement-fixation (RPCF) test (British Cooperative Clinical Group, 1972). Where necessary, the fluorescent treponemal antibody-absorbed (FTAABS) or Treponema pallidum immobilization (TPI) tests can be used for verification of treponemal infection.

The $T$. pallidum haemagglutination (TPHA) test developed by Rathlev (1965, 1967) and modified by Tomizawa (Tomizawa and Kasamatsu, 1966; Tomizawa, Kasamatsu, and Yamaya, 1969) appears to possess characteristics of both a screening and a verification test. It is simple to perform and reproducible, and has a wide spectrum of reactivity in the different stages of syphilis (Tringali, 1970) and a specificity and sensitivity comparable with the FTA-ABS and TPI tests (Garner, Backhouse, Daskalopoulos, and Walsh, 1972; Johnston, 1972; O'Neill, Warner, and Nicol, 1973). In spite of these features, the TPHA test has not yet been widely used as a routine screening procedure.

This paper assesses the suitability of the TPHA test as a screening test for syphilis in a serology laboratory serving the general hospital population, an antenatal clinic, and a Sexually-Transmitted Diseases Department.

\section{Material and methods}

CLINICAL MATERIAL

A total of 7,312 sera, derived from the following sources in the Royal Infirmary Edinburgh (RIE), were examined over a 6-month period:
Sexually-Transmitted Diseases Department (STDD)

Antenatal Clinic (ANC)

General Hospital Population (GHP)

SEROLOGICAL TESTS

All specimens were screened by the VDRL slide test, RPCF, and TPHA tests. The FTA-ABS test was carried out on all specimens reactive in any of the screening tests.

A modification of the Whitechapel technique (ACP Broadsheet 41, 1969) was used for the RPCF test (1.1 MHD of complement and a fixation period of $30 \mathrm{~min}$. at room temperature followed by $30 \mathrm{~min}$. at $37^{\circ} \mathrm{C}$.). Standard techniques were used for the VDRL slide test (Harris, Rosenberg, and Reidel, 1946) and the FTA-ABS test (Hunter, Deacon, and Meyer, 1964).

\section{TPHA TEST}

This was carried out by a modification of the micromethod described by the suppliers of the reagents (Fujizoki Pharmaceutical Company, Tokyo, Japan). Each kit comprised lyophilized test cells (antigen coated) and control cells, absorbing diluent to remove non-specific reactions, and a positive control serum. Test and control cells were re-constituted and diluted 1 in 6.5 as recommended by the manufacturer. Positive and negative control sera were included in each batch of screening tests and the positive serum titrated whenever any quantitative tests were performed.

\section{(a) Screening tests}

Sera were inactivated by heating at $56^{\circ} \mathrm{C}$. for $30 \mathrm{~min}$. and a 1 in 20 dilution of serum was made by adding $10 \mu l$. serum to $190 \mu l$. absorbing diluent. Samples were allowed to absorb for $30 \mathrm{~min}$. at room temperature, after which time 25- $\mu$ l. aliquots were transferred to U-type microtitre plates. Test cells $(75 \mu \mathrm{l}$.) were then added to each sample to give a final serum dilution of 1 in 80 . Plates were examined after $4 \mathrm{hrs}$ incubation at $25^{\circ} \mathrm{C}$. A final reading was made after overnight incubation. 
Results were recorded as follows:

$\begin{array}{ll}\text { Negative } & \begin{array}{l}\text { A smooth ring or button of cells. } \\ \text { A diffuse carpet or a thin ring of cells } \\ \text { with marked agglutination. }\end{array} \\ \text { Weak positive } & \begin{array}{l}\text { A slightly enlarged ring of cells with } \\ \text { peripheral agglutination. }\end{array} \\ \text { Doubtful } & \begin{array}{l}\text { An appearance intermediate between } \\ \text { weak positive and negative (an enlarged } \\ \text { ring of cells surrounded by a rough } \\ \text { margin.) }\end{array}\end{array}$

Specimens showing positive, weak positive, and doubtful reactions were tested quantitatively as follows:

\section{(b) Quantitative test for positive reactors}

Sera were absorbed as described previously and doubling dilutions prepared, in 25 - $\mu$ l. volumes in diluent, over the range 1 in 20 to 1 in 1,280 . Test cells $(75 \mu \mathrm{l}$.) were then added to give final serum dilutions from 1 in 80 to 1 in 5,120 . Each specimen was also tested against control cells at a final serum dilution of 1 in 80 . After incubation, the titre was read as the highest dilution giving definite agglutination.

\section{(c) Quantitative test for weak positive and doubtful reactors}

These were titrated over a range of serum dilutions from 1 in 40 to 1 in 320 by preparing an initial serum dilution of 1 in 10 in diluent. Samples were also tested against control cells at a 1 in 40 serum dilution. Specimens showing slight agglutination at 1 in 40 but doubtful agglutination or none at 1 in 80 were regarded as negative, while specimens showing strong agglutination at 1 in 40 and weak agglutination at 1 in 80 were reported as 'very weak positive' (VWP). In all other cases the titre was read as described above.

Samples showing agglutination of control cells were reported as 'Non-specific agglutination-test invalid'.

All the 35 doubtful reactors by the screening test were classed as negative when tested as described above. FTA-ABS tests on these sera were also negative.

\section{Results}

335 of the 7,312 sera examined were reactive in one or more of the screening tests; this represented 251 of the 6,500 patients examined in the course of the survey. An examination of the clinical records showed that 256 of the 335 reactive sera were from 185 cases of syphilis diagnosed by accepted clinical and serological criteria (including the TPI test in some cases).

Table I shows the number of specimens detected by each test and combination of tests, the agreement of the tests with the FTA-ABS, and their efficiency in detecting the 256 sera from cases of syphilis. The 287 sera detected by the TPHA test did not include the 35 doubtful reactors by the screening test which were classed as negative after the quantitative test.

From Table $I$ it is clear that the TPHA test was significantly more sensitive than either the VDRL or RPCF tests. A combination of the VDRL and TPHA tests detected all 256 sera from cases of syphilis.

A summarized analysis of clinical data in relation to laboratory results is shown in Table II. Full clinical information was not available for certain patients presenting at various out-patient departments associated with the hospital and for a smalb number of defaulters; these are grouped as cases with 'insufficient information'.

All specimens which were positive in all of the three screening tests were also FTA-ABS positive. Cases of untreated syphilis in this group were mainly of late syphilis (late syphilis, twelve sera; early syphilis, three sera). Sera found to be positive in both the VDRL and TPHA test and negative in the RPCF test also showed 100 per cent. agreement with the FTA-ABS test and there were no cases of untreated syphilis in this group.

The TPHA test failed to detect ten sera from patients with syphilis which were positive in the FTA-ABS. Eight of the sera were from cases of untreated primary syphilis (two were VDRL and RPCF positive and six were positive in the VDRL only) and two were specimens from a case of treated latent syphilis (positive in the VDRL only). The

TABLE I Effectiveness of individual tests or combination of tests as a screen for the detection of syphilis. Results from 7,312 sera

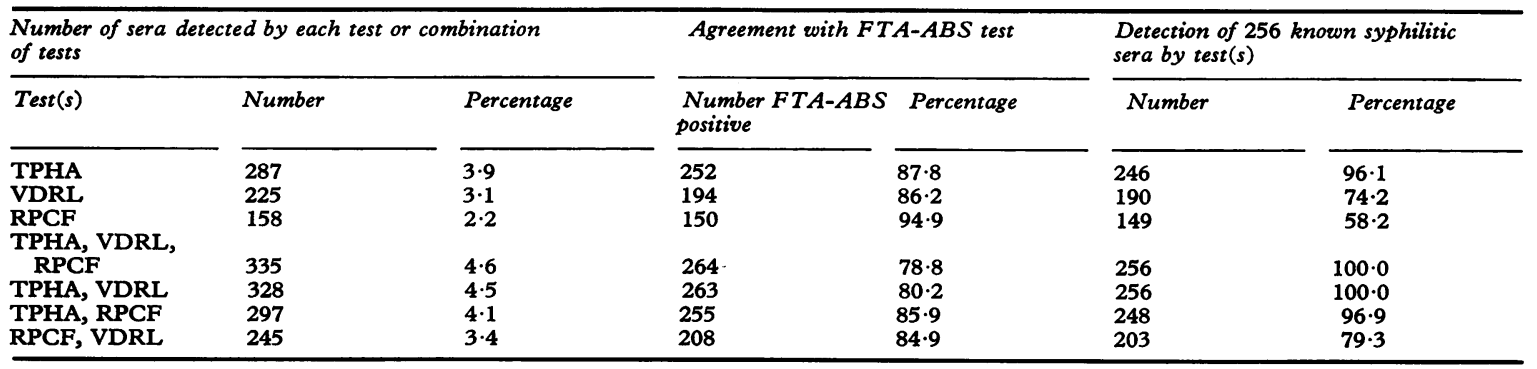


TABLE II Clinical findings in relation to laboratory results in 335 reactive sera

\begin{tabular}{|c|c|c|c|c|c|c|c|c|c|c|}
\hline \multicolumn{3}{|c|}{ Laboratory result } & \multirow[t]{2}{*}{$\begin{array}{l}\text { No. of sera } \\
\text { positive }\end{array}$} & \multicolumn{2}{|c|}{$\begin{array}{l}\text { Agreement with } \\
F T A-A B S\end{array}$} & \multicolumn{3}{|c|}{ Known syphilis } & \multirow{2}{*}{$\begin{array}{l}\text { No clinical } \\
\text { evidence or } \\
\text { history of } \\
\text { syphilis }\end{array}$} & \multirow[t]{2}{*}{$\begin{array}{l}\text { Insufficient } \\
\text { information }\end{array}$} \\
\hline$V D R L$ & $R P C F$ & TPHA & & $\begin{array}{l}\text { Number } \\
\text { FTA-ABS } \\
\text { positive }\end{array}$ & Percentage & Total & Treated & Untreated & & \\
\hline+ & + & + & 134 & 134 & 100 & 134 & 119 & 15 & 0 & 0 \\
\hline+ & - & + & 49 & 49 & 100 & 46 & 46 & 0 & 0 & 3 \\
\hline+ & - & - & 38 & 9 & $23 \cdot 7$ & 8 & 2 & 6 & 10 & 20 \\
\hline- & + & - & 7 & 1 & $14 \cdot 3$ & 0 & 0 & 0 & 4 & 3 \\
\hline
\end{tabular}

VDRL, therefore, detected all sera from patients with syphilis which were negative by the TPHA whereas the RPCF detected only two of these.

Ninety sera positive in the TPHA but negative in the $V D R L$ and RPCF tests: 56 were FTA-ABS positive and 34 negative

56 SERA POSITIVE IN THE TPHA AND FTA-ABS TESTS

45 of these sera were from cases of diagnosed syphilis (37 from patients with treated syphilis and eight from cases of untreated latent syphilis).

Of the remaining eleven specimens, five were from cases attending the STDD for treatment for gonorrhoea. There was insufficient clinical data to evaluate the remaining six sera.

\section{SERA POSITIVE IN THE TPHA TEST BUT NEGATIVE IN THE FTA-ABS TEST}

These sera were derived from 23 patients. In five of these patients there was a reliable history in keeping with the interpretation that the positive TPHA reaction was due to antibody against $T$. pallidum; these cases are summarized in Table III. In eight patients, seven of whom had attended the STDD, there was neither clinical evidence, nor a reliable history of syphilis (Table IV); sera from five of these patients gave a reciprocal TPHA titre of 160 or more on at least one occasion but repeat specimens were negative. The remaining ten patients (STDD 4; ANC 3; GHP 3), all in the 'very weak positive' category, attended once only and could not therefore be fully evaluated.

\section{Non-specific agglutination}

Four sera agglutinated both test and control cells. These sera were negative in the VDRL, RPCF, and FTA-ABS tests. This represented 0.05 per cent. of all sera tested.

The pattern of agglutination of the antigen-coated cells by these non-specific sera was found to differ from the normal agglutination pattern (Figure). The reason this for distinctive settling pattern is obscure but these sera could invariably be distinguished from genuine reactors in the routine screen in the absence of control cells.

\section{Discussion}

On the basis of the results presented, we conclude that the VDRL and TPHA tests together provide a very effective screen for treponemal infection. Both tests are simple to perform and their activity is complementary. The VDRL test is more sensitive than the TPHA in the detection of very early syphilis

TABLE III Summary of five cases in which antibody against T. pallidum was detectable by the TPHA test but not by the FTA-ABS or other tests

\begin{tabular}{|c|c|c|c|c|}
\hline $\begin{array}{l}\text { Case } \\
\text { no. }\end{array}$ & $\begin{array}{l}\text { Age } \\
\text { (yrs) }\end{array}$ & $\begin{array}{l}\text { Area } \\
\text { attended }\end{array}$ & $\begin{array}{l}\text { TPHA } \\
\text { results }\end{array}$ & Clinical state \\
\hline $\begin{array}{l}1 \\
2 \\
3\end{array}$ & $\begin{array}{l}30 \\
37 \\
55\end{array}$ & $\begin{array}{l}\text { STDD } \\
\text { STDD } \\
\text { STDD }\end{array}$ & $\begin{array}{l}\text { VWP; } 80 \\
\text { VWP; } 80 \\
80 ; \text { negative; } \\
\text { VWP }\end{array}$ & $\begin{array}{l}\text { Primary syphilis treated } 5 \text { years previously } \\
\text { Primary syphilis treated } 7 \text { years previously } \\
\text { Primary syphilis treated } 24 \text { years previously }\end{array}$ \\
\hline 4 & $<1$ & STDD & 160 & $\begin{array}{l}\text { Transplacental antibody from serologically positive mother treated with penicillin } \\
\text { before and during this pregnancy }\end{array}$ \\
\hline 5 & 65 & GHP & VWP & Neurosyphilis \\
\hline
\end{tabular}

aTPHA results are expressed as the reciprocal of the final serum dilution showing definite agglutination VWP = very weak positive 
TABLE IV A summary of TPHA results and clinical findings in eight patients in whom there was no evidence of syphilis

\begin{tabular}{|c|c|c|c|c|c|}
\hline $\begin{array}{l}\text { Case } \\
\text { no. }\end{array}$ & $\begin{array}{l}\text { Age } \\
\text { (yrs) }\end{array}$ & $\operatorname{Sex}$ & Area & $\begin{array}{l}\text { TPHA results } \\
\text { (time in days } \\
\text { from first test) }\end{array}$ & Clinical data \\
\hline 1 & 32 & $\mathbf{M}$ & STDD & $\begin{array}{l}640 \\
\text { Negative (4) } \\
160(25) \\
\text { Negative (67) }\end{array}$ & $\begin{array}{l}\text { Non-gonococcal urethritis treated with tetracycline at first visit } \\
\text { Previously treated for gonorrhoea (1968) }\end{array}$ \\
\hline 2 & 23 & $\mathbf{F}$ & STDD & $\begin{array}{l}\text { Negative } \\
320(5) \\
320(26) \\
\text { Negative (166) }\end{array}$ & $\begin{array}{l}\text { Husband had been treated for gonorrhoea } \\
\text { No abnormality detected; not treated } \\
\text { History of treated spinal tuberculosis }\end{array}$ \\
\hline 3 & 23 & $\mathbf{M}$ & STDD & $\begin{array}{l}80 \\
160(4) \\
160(25) \\
\text { Negative (81) }\end{array}$ & Non-gonococcal urethritis treated with tetracycline at first visit \\
\hline 4 & 24 & $\mathbf{M}$ & STDD & $\begin{array}{l}160 \\
\text { Negative (49) }\end{array}$ & Non-gonococcal urethritis treated with tetracycline at first visit \\
\hline 5 & 43 & $\mathbf{M}$ & STDD & $\begin{array}{l}80 \\
\text { VWP (84) } \\
80(105)\end{array}$ & Prostatitis of $18 \mathrm{mths}$ ' duration \\
\hline 6 & 19 & $\mathbf{M}$ & STDD & $\begin{array}{l}80 \\
\text { VWP (35) } \\
\text { VWP (49) }\end{array}$ & Glandular fever \\
\hline $\begin{array}{l}7 \\
8\end{array}$ & $\begin{array}{l}42 \\
19\end{array}$ & $\begin{array}{l}\text { M } \\
\text { F }\end{array}$ & $\begin{array}{l}\text { STDD } \\
\text { ANC }\end{array}$ & $\begin{array}{l}80 \\
160 \\
\text { Negative (77) }\end{array}$ & $\begin{array}{l}\text { No abnormality detected } \\
10 \text { weeks pregnant at first visit }\end{array}$ \\
\hline
\end{tabular}

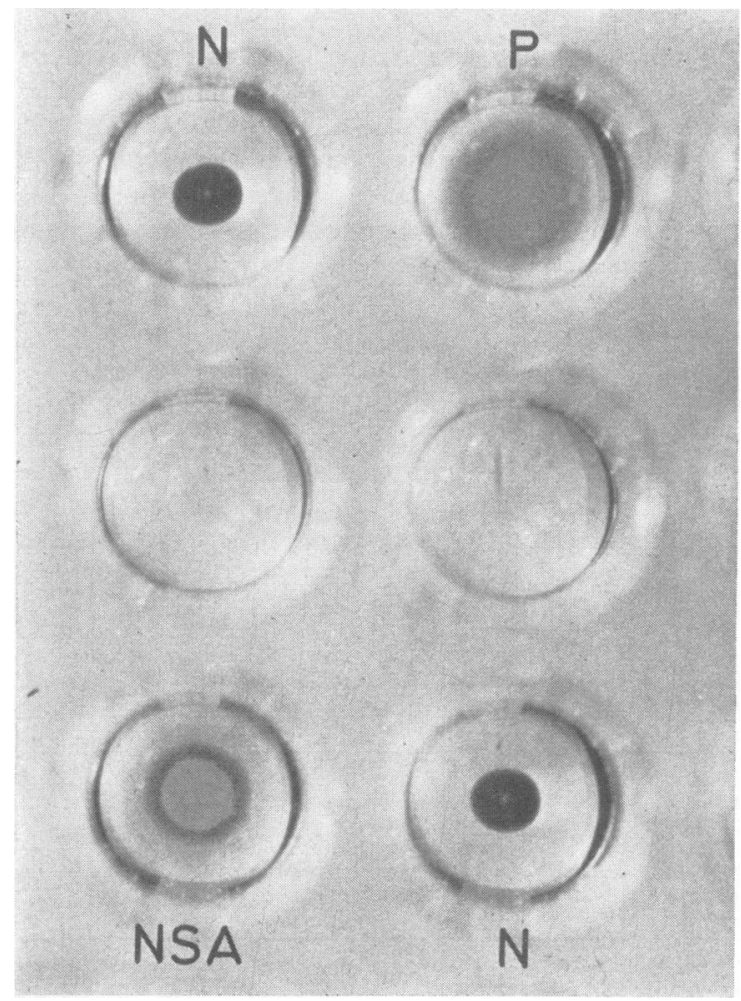

with or without a detectable chancre, while the TPHA is more sensitive and specific than the VDRL in the detection of latent or late syphilis whether treated or untreated.

Similar conclusions regarding the value of the TPHA were reached by Johnston (1972) and Sequeira and Eldridge (1973). In contrast to these findings Luger and Spendlingwimmer (1973) found the TPHA more sensitive than either the VDRL or the FTA-ABS test in untreated primary syphilis. It is of interest to note that Luger and Spendlingwimmer performed their TPHA tests without previous inactivation of sera.

The RPCF test would appear to be grossly undersensitive, detecting only 58.2 per cent. of the known syphilitic sera. Similar results were quoted in a review by Sparling (1971).

FIGURE Enlarged area (magnification $\times 3$ ) of a routine screening plate. Each well contains antigencoated cells and patient's serum.

$N=$ negative reaction

$P=$ positive reaction

NSA $=$ non-specific agglutination

In the case of the NSA, the cells have settled into a thick coarse ring with a fairly large diameter, but very little peripheral agglutination is observed. In contrast to this, the positive serum shows a thin ring of cells with marked peripheral agglutination 
The specificity of the TPHA test in our survey was 99.7 per cent. based on accepted clinical and serological criteria. 21 sera positive in the TPHA test only were from patients who had no history or clinical evidence of syphilis (Table II). However, five of these sera were also reactive in the FTA-ABS test.

Garner, Backhouse, Daskalopoulos, and Walsh (1973), in contrast to our findings and their previous work (Garner and others, 1972), found 11.3 per cent. of 274 biological false positive sera showed false positive TPHA reactions. From a survey of only 306 sera, Blum, Ellner, McCarthy, and Papachristos (1973) calculated that the TPHA test gave a false positive rate of 8.8 per cent. The reagents used in the latter study, unlike the previous one, were not supplied by the Fujizoki Company.

Sequeira and Eldridge (1973), however, using an alternative TPHA technique in which sensitized fowl erythrocytes are used in place of sheep erythrocytes, reported a specificity similar to ours $(99.8$ per cent.). Buist, Pertile, and Morris (1973) also found the TPHA test to be highly specific, giving less than 1 per cent. false positive results, while O'Neill and others (1973) reported a false positive rate of 1 in 4,000 in the general hospital population.

A transient positive TPHA reaction was given by the sera of five patients; four of these attended the STDD, three with non-gonococcal urethritis. The transient TPHA activity in this group could be due to antibody formed against an organism with a common antigen, perhaps commensal treponemes of the genital mucosa. In this context, it is of interest that three out of seven patients positive in the RPCF test only were cases of gonorrhoea; one patient having had the infection six times.

Thus one reason for the transient positive TPHA results could be the failure of the absorbing diluent to remove group-specific antibody. Sorbent will sometimes fail to remove all group treponemal antibody in the FTA-ABS test (Király, Jobbágy, and Kováts, 1967). Another reason for false positive TPHA results could be a failure of the control cells to show agglutination in the presence of heterophil antibody. Cox, Logan, and Stout (1971) reported that three of one-hundred sera from patients with infectious mononucleosis gave false positive TPHA reactions and did not agglutinate the control, unsensitized, erythrocytes. There was one such specimen in our survey. The rate of non-specific agglutination in our tests, less than 1 per thousand specimens, was relatively low compared to a rate of approximately 5 per thousand reported by Garner and others, (1972).

From our experience with the TPHA test we conclude that the main value of the test is for screening purposes. The screening schedule should also include a cardiolipin antigen test, such as the VDRL, to improve the detection of early syphilis. The FTA-ABS test should be retained as a confirmatory test for sera with equivocal results and in special cases, e.g. suspected early syphilis.

It must be recognized, however, that sera positive in the TPHA but negative in the FTA-ABS test may represent previous $T$. pallidum infection.

\section{Summary}

During a 6-month period, 7,312 sera were screened by the VDRL, RPCF and TPHA tests. Sera reactive in any of these tests were then examined by the FTA-ABS test. The sensitivity and specificity of each test was calculated on the basis of accepted clinical and serological criteria.

The TPHA test had a specificity of 99.7 per cent. and, except in cases of untreated primary syphilis, was the most sensitive of the 3 screening tests detecting 96.1 per cent. of known syphilitic sera; the VDRL detected $74 \cdot 2$ per cent. and the RPCF only 58.2 per cent. All cases of untreated primary syphilis, negative in the TPHA were detected by the VDRL test. 23 patients whose sera were reactive in the TPHA test but negative in all other tests including the FTA-ABS are discussed; 5 of these had a reliable history of syphilis.

The TPHA test and VDRL slide test were found to be a good combination for screening. However, the FTA-ABS test is still required to resolve cases which give equivocal results.

\section{References}

Association of Clinical Pathologists (1969) "Serological tests for Syphilis", by A. E. Wilkinson. Broadsheet 41

Blum, G., Ellner, P. D., McCarthy, L. R., and Papachristos, T. (1973) f. infect. Dis., 127, 321

British Co-operative Clinical Group (1972) Brit. $\mathcal{f}$. vener. Dis., 48, 254

Buist, D. G. P., Pertile, R., and Morris, G. J. (1973) Pathology, 5, 249

Cox, P. M., Logan, L. C., and Stout, G. W. (1971) Publ. Hlth Lab. (Wash.), 29, 43

Garner, M. F., Backhouse, J. L., Daskalopoulos, G., and WALSH, J. L. (1972) Brit. F. vener. Dis., 48, 470

$-,-\longrightarrow,-(1973$ F. clin. Path., 26, 258

Harris, A., Rosenberg, A. A., and Riedel, L. M. (1946) f. vener. Dis. Inform., 27, 169

HuNTER, E. F., DeAcon, W. E. and MeYer, P. E. (1964) Publ. Hlth Rep. (Wash.), 79, 410

Johnston, N. A. (1972) Brit. F. vener. Dis., 48, 474

KIRÁLY, K., JoBbÁGY, A., and KovÁts, L. (1967) f. invest. Derm., 48, 98

LUGER, A., and SPENDlingwimmer, I. (1973) Brit. $\mathcal{F}$. vener. Dis., 49, 181 
O'NeILl, P., WARNER, R. W., and Nicol, C. S. (1973) Ibid., 49, 427

RATHLEV, T. (1965) W.H.O. VDT/RES/65.77

(1967) Brit. F. vener. Dis., 43, 181

Skqueira, P. J. L. and EldRIDGe, A. E. (1973) Ibid., 49, 242

Sparling, P. F. (1971) New Engl. f. Med., 284, 642

TomizaWA, T. and Kasamatsu, S. (1966) fap. f. med. Sci. Biol., 19, 305

$\longrightarrow,-$, and YAMAYA, S. (1969) Ibid., 22, 341

Tringali, G. (1970) Ann. Sclavo, 12, 311

Le test d'hémaglutination du Treponema pallidum dans les épreuves de dépistage en vue du diagnostic de la syphilis

\section{SOMMAIRE}

Pendant une période de 6 mois, 7.312 sérums furent systématiquement soumis aux épreuves VDRL, RPCF et
TPHA. Tous les sérums réactifs à l'un de ces tests furent examinés à l'épreuve FTA-ABS. La sensibilité et la spécificité de chaque épreuve fut établie sur la base des critères acceptés en clinique et en sérologie.

Le TPHA montra une spécificité de 99,7 pour cent, détectant, sauf en cas de syphilis primaire non traitée, 96,1 pour cent des sérums syphilitiques connus et se montrant la plus sensibles des trois épreuves de diagnostic; le VDRL reconnut 74,2 pour cent des cas et le RPCF seulement 58,2 pour cent. Tous les cas de syphilis primaire non traités, négatifs avec le TPHA, furent détectés par le VDRL. 23 malades, dont le sérum était positif au TPHA mais négatif à tous les autres tests, dont le FTA-ABS, sont discutés; 5 d'entre eux avaient des antécédents valables de syphilis.

Pour le dépistage, le TPHA et le VDRL sur lame constituent une bonne association. Cependant, l'épreuve FTA-ABS est toujours nécessaire pour résoudre les cas où les résultats sont équivoques. 